\title{
The Quality of Corporate Governance and Its Effect on Sharia Bank Financial Performance in Indonesia
}

\author{
Susy Muchtar, Powell Gian Hartono*, Wahyuni Rusliyana Sari \\ Faculty of Economics and Business \\ Trisakti University \\ Jakarta, Indonesia \\ *powell022167008@std.trisakti.ac.id
}

\begin{abstract}
The research examines factors that impact financial performance of Islamic Banks. It focuses on the banks listed at Bank Indonesia (BI) and the Financial Services Authority of Indonesia (OJK). The independent variables examined include the efficiency of the Board of Directors, Audit Committee, and Sharia Supervisory Board (SSB), as well as the size, age and equity of the bank. The dependent variable includes the Islamic Bank's Financial Performance, which is determined using Return on Equity (ROE). Also, the study uses samples of 11 Islamic banks registered at BI and OJK from 2013 to 2017. They were selected using purposive sampling with specific criteria for sample withdrawal and panel data used in processes. The results showed that the Board of Director Effectiveness and Leverage had a significant positive effect on ROE. However, the Audit Committee Effectiveness, Shariah Supervisory Board Effectiveness, Bank Size, Age Bank did not affect ROE. Islamic banks need to pay attention to the factors that influence financial performance, especially the effectiveness of the Board of Directors. This is because their decisions directly contribute to the bank's performance. For investors, they can see the profits and losses the companies make from year to year through financial statements. They might also determine the quality of corporate governance from the annual reports.
\end{abstract}

Keywords-corporate governance, bank size, bank age, bank leverage, return on equity

\section{INTRODUCTION}

Corporate governance $(\mathrm{CG})$ is perceived to be a system through which organizations are managed and directed. It involves three key elements, including the management, the board or directors, and other shareholders [1]. The main goal of OCG is to maximize the welfare of owners, as well as safeguarding property rights and contractual obligations [2]. It facilitates effective management and ensure there is legal compliance, deterring the possibilities of unlawful and inappropriate conduct. Nevertheless, CG in banks has been the center of attention lately. For instance, it is still being analyzed at the Islamic Banks (IB). Little is known about their conceptions of CG, as well as the steps are taken to ensure the welfare of their stakeholders [3]. This study critically examines CG and forms the basis of determining its quality on IB financial performance [4]. Although Islamic finance is not well-established, it has lately been the center of attention among economists. This attributed to its speedy growth along with its potential to offer a competitive market. In general, IB is used as a mechanism for mobilization and apportioning of international funds [5].

The features of IB provide other layers of governance apart from the ordinary board of directors. The extra form of management has completely amended the form of management, from single to a multi-layered [5,6]. However, the presence of a CG structure for Islamic banking, specifically the Shariah Supervisory Board (SSB) is noticeable. SSB is a body that primarily focuses on ensuring institutions transact and runs according to the IFL. It is an independent body that has specialized in Islamic economic legal system and professionals in Islamic finance [7]. To ensure that all operations carried out by are Shariah-compliant, the services of a religious council known as the Sharia supervisory board (SSB) are employed. SSB is a critical aspect of the Islamicbased governance approach at IFI, especially in regulation and consultation in IFI. It intensely impacts the finance practices and IFI activities by offering relevant suggestions and ideas. In the recent past, several countries have developed an allinclusive governance structures for Sharia issues in response to the needs of IFI's [8].

This research investigates the Sharia supervision system at IFI and the problems and challenges faced by a secure Sharia supervision system [8]. Following CG practices is beneficial in several ways, such as improving the reallocation of interests between key stakeholders. Nevertheless, following CG practices does not guarantee improvement in the company performance. For this reason,, there is need to come up with a suitable agreement that lessens agency costs by restricting and disciplining executives of the organizations [9].

Islamic banks use SSB as an autonomous control mechanism. The body restricts directors and other executives from making high-risk investments [10]. These restrictions have enhanced accountability and financial disclosure, encouraging only less-risky investments [5]. There is a controversy between researchers thinking that CG in IB is the 
same as that in conventional banks, and those perceiving CG in IB as different from those in traditional CG IB. The assessment of quality requires more in-depth investigation.

\section{LITERATURE REVIEW}

\section{A. Islamic Bank's Financial Performance}

Islamic banks have a different performance structure, and therefore need to be studied independently. In reality, they operate under Sharia rules, according to the principle of profit and loss sharing. However, financial and monetary performance varies from country to country [11]. The focus of Islamic finance is often based on spiritual values as well as justice for everyone in the society. Its main goal is to optimize individual utility, well-being, and choice [12]. Although its objectives appear similar to those of conventional banking, it is primarily based on Sharia rules, specifically known as Fiqh alMuamalat. The most common concepts used in Islamic banking include Mudarabah, Wadiah, Musharaka, Murabahah, and Ijara, which means profit sharing, storage, joint ventures, plus costs, and leasing, respectively [13]. These principles are critical in the management of financial instruments, arbitrators, and markets [14]. Returns on Equity (ROE) is used to determine shareholders gain and to ensure there is sufficient capital. In general, the greater the equity capital, the smaller the ROE [15].

\section{B. Corporate Governance Quality}

OG is critical in adopting ethical practices and relating with key stakeholders in an organization. It promotes and directs management and legal compliance, apart from discouraging illegitimate and wrong behavior [3]. According to this theory, the opportunistic nature of executives is determined by the governance structure [16]. In, Islamic banking, stakeholder have various interests apart from wealth maximization. For instance, they are bound to following ethical aspects and IFL [5].

\section{Board of Director Effectiveness}

The main role of a BOD is to monitor the conduct of managers [17]. Agency theory advocates for a huge proportion of outside independent directors and the distinction between the responsibilities of the CEO and the board chairman. This enhances transparency and accountability, ensuring that supervisory is conducted effectively [18].

\section{Audit Committee Effectiveness}

The efficiency of an audit committee facilitates timely release of audit reports [19]. The independence of the members of the audit team enhances their responsibility of ensuring the reports issued are quality and realistic [4]. Contrastingly, a previous research show a huge committee allows subcommittees assess to the tasks performed by external auditors [20]. An organization with a large committee often issue reports on time [19,21]. A recent study established that there is an inverse relationship between the effectiveness of the audit team and the delay in reporting for companies in Indonesia [22].

\section{E. Shariah Supervisory Board effectiveness}

Factors that influence the Board of Directors might also affect the SSB. This is due to the fact that the roles of the Directors, audit teams, and SSB are not distinct [5]. Also, the CG and the conventional board often appear similar [2]. Previous studies focused on the impact of SSB size on IB's performance. They established that SSB size significantly impact profitability [6,23].

\section{F. Bank Size}

This is the size of the bank based on the natural logarithm of its overall assets [24,25]. Banks with sizeable total asset value with increasing profitability creates opportunities for other institutions to be stable [26]. Larger institutions use liberal lending policies with loose standards, leading to poor performance [25].

\section{G. Age Bank}

Older companies are often more optimal compared to new ones, though this is primarily due to the learning curve and survival bias [27]. Age is another significant variable often linked Performance [28]. However, older entities are comparatively less efficient due to higher costs, outdated assets, less investment on research and development, inappropriate governance measures, and larger boards, which negatively affect performance [29]. Age is determined by the number from the time of formation [30].

\section{H. Bank Leverage}

Previous works established that leverage negatively impacts performance [5,31]. In general, banks with substantial capital often utilize internal resources to fund investments before turning to external sources. Banks with a lot of assets and less debt often increase their investments and performance [32]. Bank leverage (LEV) is determined as the ratio of overall debt to overall assets $[5,9,33]$.

\section{Hypothesis Development}

The primary function of the council is to monitor, advise, and provide resources [34]. Agency theory holds that CEO duality persuades the executive to lead the board for personal interests by giving limited information (private information) about a company [35]. The theory recommends the separation of the CEO's role and Chief of Board to improve monitoring and to avoid the entrenchment on the executive [36]. IB's with high BOD scores have an effective structure that improves financial performance [4].

H1: The Effectiveness of the Board of Directors on the Islamic Bank's financial performance.

An active audit committee can easily identified and deter dishonest and misleading statements, control opportunistic 
learning and problems associated with internal control [37]. There is an inverse relationship between the number of meetings and late management reporting. In general, the number of meetings held optimize internal control [38]. The AC-index blends several factors, including the effectiveness of $\mathrm{AC}$, size, impartiality, and rate of recurrence of meetings. A greater AC score shows a more appropriate system in the IB that optimizes the overall financial performance [4].

H2: The effectiveness of the Audit Committee influences the Islamic Bank's financial performance.

In many banks, SSBs have been replaced since their scholars lack adequate knowledge and experience in sharia principles and lack product awareness [39]. The scholars with adequate understanding of accounting and finance optimizes the IB performance. Essentially, appropriate understanding in Sharia's law often boosts performance of IBs [23,40]. The Accounting and Auditing Organization for Islamic Financial Institutions (AAOIFI) advocates for three SSB members, one with understanding of the Islamic economics [7].

H3: The effectiveness of the Shariah Supervisory Board affects the Islamic Bank's financial performance.

Established Islamic banks have the option of investing in various profit-sharing instruments to reduce the risk of loss following Sharia principles and rules. Consequently, they value products and services at relatively lower costs and higher profits [5]

H4: Bank Size affects the Islamic Bank's financial performance.

Issues relating to the superiority of organizations based on age have been debatable for long. The data from the US show that older entities limits production and decrease Tobin's Q ratio [29].

\section{H5: Age affects Islamic Bank's financial performance.}

According to previous works, capital has a significant negative impact on performance [5,31]. Islamic banks with sufficient capital often utilizes internal resources to fund investments before turning to external funds. Banks with substantial assets and low debt improves investment and performance [32]

H6: Bank Leverage affects Islamic Bank's financial performance.

\section{METHODS}

Based on the chow test, the cross-section Chi-square Return on Equity probability value of $0.000<0.05$, the decision is a fixed effect. Following the Hausman test, the cross-section Statistics Return on Equity probability value of $0.0041<0.05$ is a fixed effect decision.

\section{RESULTS AND DISCUSSION}

\section{A. Results}

The panel data regression is used in this research and the results are on table 1 as follows:

TABLE I. T-TEST RESULT

\begin{tabular}{|l|l|l|l|}
\hline \multicolumn{1}{|c|}{ Variable } & Coefficient & \multicolumn{1}{|c|}{ Prob. } & Information \\
\hline Constanta of Director & -241.2649 & 0.3377 & - \\
\hline $\begin{array}{l}\text { Board Committee } \\
\text { Effectiveness }\end{array}$ & -8.587641 & $0.0127 *$ & Significant \\
\hline $\begin{array}{l}\text { Audit } \\
\text { Effectiveness }\end{array}$ & -1.819811 & 0.9532 & Not significant \\
\hline $\begin{array}{l}\text { Shariah Supervisory Board } \\
\text { effectiveness }\end{array}$ & -2.131772 & 0.1549 & Not significant \\
\hline Bank Size & 10.41398 & 0.2173 & Not significant \\
\hline Age Bank & 5,626143 & $0.0759 *$ & Significant \\
\hline Bank Leverage & \multicolumn{3}{|c}{} \\
\hline
\end{tabular}

Return on Equity $=-241.2649+54.04412$ Board of Directors Effectiveness - 8.587641 Audit Committee Effectiveness 1.819811 Shariah Supervisory Board Effectiveness - 2.131772 Bank Size + 10.41398 Bank Age + 5.626143 Bank Leverage

\section{B. Discussion}

The results showed that the effectiveness of the Board of Directors had a positive impact on Return on Equity. This result is linear and supported previous research [41], though not consistent with other studies [4]. In line with this idea, bank financial performance is positively impacted by the effectiveness of the board of directors [42]. Islamic banks with high BOD - index scores are considered to have an effective structure that can improve their financial performance [43]. The results showed that there is no relationship between the Audit Committee Effectiveness and Return on Equity. These are consistent with previous research [4]. According to previous works, independent $\mathrm{AC}$ and its size do not influence performance [44]. From Wild, AC's primary focus is to warrant quality published reports but cannot enhance financial performance [45].

This research showed that the Shariah Supervisory Board Effectiveness and ROE do not correlate, which is in line with previous works [4]. Also, there is no relationship between Bank Size and ROE, though this contradicts previous works [4]. A large size does not primarily enhance financial performance in Islamic banks. The large size of the bank does not guarantee the optimization of profits due to other burdens [46].

This research established that bank age has no effect on the Return on Equity, which is in line with previous work [4]. However, there is a significant relationship between Capital and ROE, a finding in line with a previous study [5]. Banks with substantial capital often utilize internal resources to fund investments before considering external sources. In case a bank 
has more assets and low debt, it is more likely to increase investment, and therefore, performance upsurges [31].

\section{CONCLUSION}

This study concludes that there is significant positive relationship between the effectiveness of Board of Directors and Islamic Bank Financial Performance, which is determined by ROE. Effectiveness of the Audit Committee and the Shariah Supervisory Board, Size, and Age does not impact Financial Performance as determined by ROE. Therefore, there is need for the management to consider corporate governance factors to encourage transparency, accountability and openness in financial disclosure. An effective corporate governance proves that an entity considers the needs of its stakeholders. Also, future studies should focus on other variables namely listing ownership and board independence [8].

\section{REFERENCES}

[1] OECD "G20/OECD Principles of Corporate Governance," [online] Retrieved from www.oecd.org/corporate/principles-corporategovernace.htm

[2] M. Bhatti and I. Bhatti, "Development in legal Issues of Corporate Governance in Islamic Finance," J Econ Adm Sci., vol. 25, no. 1, pp 67-91, 2009.

[3] H.A.N. Al-Malkawi, R. Pillai and M.I. Bhatti, "Corporate governance practices in emerging markets: The case of GCC countries," Econ Model, vol. 38, pp. 133-41, 2014.

[4] H. Ajili and A. Bouri, "Corporate governance quality of Islamic banks: measurement and effect on financial performance," Int J Islam Middle East Financ Manag, vol. 11, no. 3, pp. 470-87, 2018.

[5] A.A. Bukair and A.A. Rahman, "Bank performance and board of directors attributes by Islamic banks," Int J Islam Middle East Financ Manag., vol. 8, no. 3, pp. 291-309, 2015.

[6] S. Mollah and M. Zaman, "Shari'ah supervision, corporate governance and performance: Conventional vs. Islamic banks," J Bank Financ, vol. 58, pp. 418-35, 2015

[7] AAOIFI, Governance Standard for Islamic financial institutions Bahrain: Accounting and Auditing Organization for Islamic Financial Institutions, 2010.

[8] R. Grassa, "Shariah supervisory system in Islamic financial institutions: New issues and challenges: A comparative analysis between Southeast Asia models and GCC models," Humanomics, vol. 29, no. 4, pp. 333 48, 2013.

[9] S. Akbar, J. Poletti-Hughes, R. El-Faitouri and S.Z.A. Shah, "More on the relationship between corporate governance and firm performance in the UK: Evidence from the application of generalized method of moments estimation," Res Int Bus Financ, vol. 38, pp. 417-29, 2016.

[10] M.K. Hassan and S. Mollah, "Corporate governance, risk-taking and firm performance of islamic banks during global financial crisis," In Finance and Development in Islamic Economies Conference, 2014.

[11] S.B.S. Zouari and N.B. Taktak, "Ownership structure and financial performance in Islamic banks: Does bank ownership matter?" Int J Islam Middle East Financ Manag., vol. 7, no. 2, pp. 146-60, 2014.

[12] I. Tlemsani and H.A.L. Suwaidi, "Comparative Analysis of Islamic and Conventional Banks in the UAE During the Financial Crisis," Asian Econ Financ Rev, vol. 6, no. 6, pp. 298-309, 2016.

[13] M.H. Uddin, "Measuring the Performance of Islamic Banks in Bangladesh : An Exploratory Study. Int J Ethics Soc Sci," vol. 2, no. 1, pp. 73-94, 2014.
[14] M.M. Ashraf and Z. Rehman, "The Performance Analysis of Islamic and Conventional Banks: The Pakistan's Perspective," J Money, Invest Bank, vol. 22, pp. 99-113, 2011

[15] P.M.A. Petersen and I. Schoeman, "Modeling of Banking Profit via Return-on-Assets and Return-on-Equity," Lect Notes Eng Comput Sci. vol. 2171, no. 1, pp. 828-33, 2008.

[16] S. Mollah, M.K. Hassan, O. Al Farooque, and A. Mobarek, "The governance, risk-taking, and performance of Islamic banks," J Financ Serv Res, vol. 51, no. 2, pp. 195-219, 2017.

[17] M.C. Jensen and W.H. Meckling, "Theory of the Firm: Managerial," J financ econ., vol. 3:, pp. 305-60, 1976

[18] J. Darko, Z.A. Aribi, and G.C. Uzonwanne, "Corporate governance: the impact of director and board structure, ownership structure and corporate control on the performance of listed companies on the Ghana stock exchange," Corp Gov., vol. 16, no. 2, pp. 259-77, 2016.

[19] S.P. Nelson and S.N. Shukeri, Corporate governance and audit report timeliness: Evidence from Malaysia, vol. 11. Research in Accounting in Emerging Economies. Emerald Group Publishing Ltd, 2011.

[20] M.M. Rahmat, T.M. Iskandar and N.M. Saleh, "Audit committee characteristics in financially distressed and non-distressed companies." Manag Audit J., vol. 24, no. 7, pp. 624-38, 2009.

[21] M.N. Mohamad-nor, R. Shafie and W.N. Wan-hussin, "Corporate Governance And Audit Report Lag In Malaysia," Asian Acad Manag J Account Financ, vol. 6, no. 2, pp. 57-84, 2010.

[22] S.R. Ika and N.A. Mohd Ghazali, "Audit committee effectiveness and timeliness of reporting: Indonesian evidence," Manag Audit J., vol. 27 no. 4, pp. 403-24, 2012

[23] R. Grassa and H. Matoussi, "Is corporate governance different for Islamic banks A comparative analysis between the Gulf Cooperation Council and Southeast Asian countries," Int J Bus Gov Ethics, vol. 9, no. 1, pp. 27-51, 2014.

[24] E. Menicucci and G. Paolucci, "The determinants of bank profitability: empirical evidence from European banking sector," J Financ Report Account, vol. 14, no. 1, pp. 86-115, 2016

[25] A. Ghosh, "Determinants of bank loan charge-off rates: evidence from the USA," J Financ Regul Compliance, vol. 26, no. 4, pp. 526-42, 2018.

[26] M. Adusei, "Bank profitability: Insights from the rural banking industry in Ghana," Cogent Econ Financ., vol. 3, no. 1, pp. 1-15, 2015.

[27] N. Rajput and B. Joshi, "Shareholder Types, Corporate Governance and Firm Performance: An Anecdote from Indian Corporate Sector," Asian J Financ Account, vol. 7, no. 1, p. 45, 2014.

[28] Y.G. Shan and R.P. McIver, "Corporate governance mechanisms and financial performance in china: Panel data evidence on listed non financial companies," Asia Pacific Bus Rev, vol. 17, no. 3, pp. 301-24, 2011.

[29] C. Loeder and U. Waelchli, "Firm age and performance." J Evol Econ., vol. 28, no. 1, pp. 1-52, 2010.

[30] M. Ammann, D. Oesch and M.M. Schmid, "Corporate governance and firm value: International evidence,” J Empir Financ., vol. 18, no. 1, pp. 36-55, 2011.

[31] M. Al-Saidi and B. Al-Shammari, "Ownership concentration, ownership composition and the performance of the Kuwaiti listed non-financial firms," Int J Commer Manag., vol. 25, no. 1, pp. 108-32, 2015.

[32] A.A. Bukair, "Influencing of Specific-Firm Characteristics on Islamic banks Profitability: Evidence from GCC Countries," Am Acad Sch Res J, vol. 5, no. 4, pp. 110-24, 2013.

[33] E.R. Outa and N.M. Waweru, "Corporate governance guidelines compliance and firm financial performance: Kenya listed companies,' Manag Audit J., vol. 31, no. 8-9, pp. 891-914, 2016.

[34] C.G. Ntim, "Board diversity and organizational valuation: unravelling the effects of ethnicity and gender," J Manag Gov., vol. 19, no. 1, pp. 167-95, 2013.

[35] A. Ujunwa, "Board characteristics and the financial performance of Nigerian quoted firms," Corp Gov, vol. 12, no. 5, pp. 656-74, 2012. 
[36] J.D. Mahadeo, T. Soobaroyen, and V.O. Hanuman, "Board Composition and Financial Performance: Uncovering the Effects of Diversity in an Emerging Economy,” J Bus Ethics., vol. 105, no. 3, pp. 375-88, 2012.

[37] M. Allegrini and G. Greco, "Corporate boards, audit committees and voluntary disclosure: Evidence from Italian Listed Companies,” J Manag Gov., vol. 17, no. 1, pp. 187-216, 2013.

[38] H. Khlif and K. Samaha, "Internal control quality, Egyptian standards on auditing and external audit delays: Evidence from the Egyptian stock exchange,” Int J Audit, vol. 18, no. 2, pp. 139-54, 2013.

[39] M.D. Bakar, Shariah Minds in Islamic Finance. Kuala Lumpur: Amanie Media Sdn. bhd., 2016.

[40] R. Grassa, "Corporate governance and credit rating in Islamic banks: Does Shariah governance matters?" Journal of Management and Governance, 2016.

[41] P. de Andres and E. Vallelado, "Corporate governance in banking: The role of the board of directors," J Bank Financ, vol. 32, no. 12, pp. 2570 80, 2008.
[42] M.F. Al Manaseer, R.M. Al-Hindawi, M.A. Al-Dahiyat and I.I. Sartawi, "The impact of corporate governance on the performance of Jordanian banks," Eur J Sci Res., vol. 67, no. 3, pp. 349-59, 2012.

[43] ECGI, "GCC countries corporate governance codes (Bahrain, Qatar, Kuwait, UAE, KSA and Oman)," [online] retrieved from Www.ecgi.org/codes/

[44] L.D. Brown and M.L. Caylor, "Corporate governance and firm valuation," J Account Public Policy, vol. 25, no. 4, pp. 409-34, 2006

[45] J.J. Wild, "The Audit Committee and Earnings Quality," J Accounting, Audit Financ., vol. 11, no. 2, pp. 247-76, 1996.

[46] K. Taani and M.H.H. Banykhaled, "The Effect of Financial Ratios, Firm Size and Cash Flows From Operating Activities on Earnings Per Share: (an Applied Study: on Jordanian Industrial Sector)," Int J Soc Sci Humanit Stud, vol. 3, no. 1, pp. 197-205, 2011. 